\title{
KUTATÁSI BESZÁMOLÓ
}

\author{
ADAMIK BÉLA \\ IN MEMORIAM HERMAN JÓZSEF: \\ A KÉSŐ LATIN NYELVTÖRTÉNETI ADATTÁRTÓL \\ A CSÁSZÁRKORI LATIN FELIRATOK SZÁMÍTÓGÉPES \\ NYELVTÖRTÉNETI ADATBÁZISÁIG*
}

\section{A Herman-féle Késő Latin Nyelvtörténeti Addattár és tudománytörténeti háttere}

A huszadik század a latin nyelvészetben nem volt a dialektológiai és a nyelvföldrajzi kutatások fénykora. Bár hatalmas, térben és időben jól elrendezhető nyelvi anyag áll a kutatás rendelkezésére, tudniillik a feliratok százezres nagyságrendű korpusza, mégsem találhatók a Római Birodalom hatalmas latin nyelvü területéről erre az anyagra épülő dialektológiai munkák vagy nyelvatlaszok. ${ }^{1}$ Hiányoznak azok az általánosabb, összefoglaló jellegű leírások is, amelyekből az érdeklődő képet kaphatna az Imperium Romanum feliratos latinságáról. Valójában csupán részterületek feldolgozásaira vagyunk utalva, amelyek vagy egy földrajzi egység (pl. egy provincia), vagy egy társadalmi réteg (pl. keresztények), vagy egy nyelvi alrendszer (pl. névszói morfoszintaxis) tekintetében írják le a feliratok nyelvét.

E helyzet kialakulásának okait részletesen bemutatni itt nem áll módunkban, de a következő megállapítás a leglényegesebb okot vélhetően kellően megvilágítja. A latin nyelvföldrajz létre nem jöttéért leginkább egyfajta szkepszis tehető felelőssé, amelyik időről időre megfogalmazódott a latin nyelv területi változatainak megismerhetőségével kapcsolatban. ${ }^{2}$ E szkepszis első hulláma a 20. század első felében jelentkezett, miután napvilágot láttak a feliratos anyagról az első provincialeírások, a kéziratos hagyományozású késő ókori szövegek vonatkozásában pedig az első nagy auktorleírások. ${ }^{3}$ Ezek az úttörő munkák ugyanis mind arra a megállapításra jutottak, hogy a feliratok és más

\footnotetext{
* B. Adamik: In memoriam József Herman: von der Late Latin Data Base bis zur Computerized Historical Linguistic Database of Latin Inscriptions of the Imperial Age. Acta Ant. Hung. 49 (2009) 11-22. átdolgozott, aktualizált magyar nyelvü változata, amely a K 62032 ny. sz. „Császárkori latin feliratok számítógépes nyelvtörténeti adatbázisa" c. OTKA-Projekt keretében készült.

${ }^{1}$ Ebből a szempontból J. N. Adams tanulmánya (The Regional Diversification of Latin 200 BC - AD 600. Cambridge 2007) sem hozott áttörést, mert alapvetően nem a feliratos anyagra támaszkodik, illetve a feliratok dialektológiai hasznosításáról szóló (10.) fejezete metodikailag nagyrészt téves alapokon nyugszik.

2 Legutóbb J. N. Adams: i. m. 3 skk., kül. 7. és 624 skk.

3 J. Pirson: La langue des inscriptions latines de la Gaule. Bruxelles 1901., A. Carnoy: Le latin d'Espagne d'après les inscriptions. Bruxelles 1906., P. Skok: Pojave vulgarno-latinskoga jezika na natpisima rimske provincije Dalmacije. Zagreb 1915. és M. Bonnet: Le latin de Grégoire de Tours. Paris 1890.
} 
szövegfajták lényegében mindenhol ugyanazokat a vulgarizmusokat, az írott normanyelvtől való jellegzetes eltérésekben tetten érhető beszélt nyelvi jelenségeket mutatják. Ebből pedig adódott a kézenfekvő konklúzió, hogy a birodalom területén a beszélt latin nyelvnek lényegében egységesnek kellett lennie, és a nyelvi differenciáció, a markáns területi nyelvváltozatok kialakulása csak kb. 600 után indulhatott meg. Ez a dialektológiai szempontból igen deprimáló következtetés - és belőle fakadóan a római birodalom latin fele nyelvföldrajzi egységességének feltételezése ${ }^{4}$ - hosszú ideig fékezte, sőt teljesen le is állította a latin nyelvföldrajzi kutatásokat és a provinciák feliratkorpuszainak nyelvészeti, dialektológiai feldolgozását.

Ez a szkepszis csak a 20. század hatvanas éveiben kezdett enyhülni, amikor is Herman József és mások új metodikájú kutatásai ${ }^{5}$ végre új eredményeket kezdtek hozni a tetszhalott állapotban lévő latin nyelvföldrajzi kutatások terén. Elsősorban Herman József vizsgálatai mutatták azt ki, hogy a latin nyelvterület már a császárkorban sem volt teljesen egységes, rajta olyasfajta differenciáció jeleit lehet felfedezni, amelyet bátran lehet dialektalizációnak vagy regionalizációnak nevezni. ${ }^{6} \mathrm{~A}$ regionális változatok közötti eltéréseket Herman József úgy jellemezte, hogy azok nem annyira területenként külön irányú, divergens fejlődést tükröznek, mint inkább lényegileg azonos változási tendenciák késleltetett vagy gyorsabb megjelenését, érvényesülését. ${ }^{7}$ Herman József ezeket a regionális különbségeket nyelvföldrajzi térképen is ábrázolta, és addigi kutatási eredményei alapján 1985-ben kísérletet tett a császárkori latin nyelvterület egészének átfogó dialektológiai jellemzésére is. ${ }^{8}$

Ez az új irányzat megszabadította a latin dialektológiai kutatásokat attól a romanisztikai ihletettségű látásmódtól, amelyik mindig román/újlatin típusú területi különbségeket, illetve azok előzményeit akarta mindenáron megtalálni a latin anyagban. Megteremtődtek egy önálló, az újlatin/román nyelvföldrajztól független latin dialektológia és nyelvföldrajz elméleti feltételei. Megfogalmazódott a remény, hogy ezentúl a latin szöveganyagot már nem csak az összromán fejlődések illusztratív példaanyagaként fogják felhasználni, és hogy a latin nyelvemlékeket nem fogják többé pusztán kulisszának tekinteni, amelyek mögött, számunkra megismerhetetlenül és örökre elfedve zajlanak a nyelvi tagolódás folyamatai. Testet öltöttek olyan elvárások, hogy majd innentől kezdve

${ }^{4}$ Az egységesség mellett érvelt E. Löfstedt: Late Latin. Oslo 1959. 9 és 48, ellene vö. J. Herman: Új eredmények, új kérdések a román nyelvek kialakulási folyamatának vizsgálatában (Akadémiai székfoglaló, 1982. december 13). Budapest 1985 és J. Herman: Les variétés du latin. Lexikon der Romanistischen Linguistik 2.1. Tübingen, 1996. 44-61, kül. 57.

${ }^{5}$ Vö. J. Herman: i. m. (1985, 4. jegyz.) 19 sk., továbbá J. Herman: La différenciation territoriale du latin et la formation des langues romanes $(1985)=J$. Herman: Du latin aux langues romanes. Études de linguistique historique. (réun. S. Kiss). Tübingen 1990. 62-92, 62 skk. és J. Herman: i. m. (1996, 4. jegyz.) 45 skk.

6 Vö. J. Herman: i. m. (1985, 4. jegyz.) 33, J. Herman: i. m. (5. jegyz.) 89, J. Herman: i. m. (1996, 4. jegyz.) 56 sk.

7 Vö. J. Herman: i. m. (1985, 4. jegyz.) 34. és J. Herman: Vulgáris Latin. Az újlatin nyelvek kialakulásának útja. Budapest 2003, 89 skk.

${ }^{8}$ Vö. J. Herman: i. m. (5. jegyz.) 87, (a 92. o. utáni 4. térképpel együtt). 
a latin anyagot öncélúan és intenzíven fogják kutatni, és megszületik a régen várt latin dialektológia és nyelvföldrajz.

De az új módszerekkel elért első részeredmények pozitív és lelkes fogadtatását nem követték ugyanolyan lelkes és intenzív munkálatok. Igazából Herman József volt szinte az egyetlen, ${ }^{9}$ aki latin nyelvföldrajzi jellegü tanulmányaiban mindvégig következetesen és sikeresen alkalmazta az általa kidolgozott új metodikát: legutóbb egy 2000-ben megjelent olasz nyelvủ tanulmányában, amelyben metodikája elméleti alapjainak ragyogó összefoglalásán túl módszertanának példaszerủ és sikeres gyakorlati alkalmazását is bemutatta, mégpedig itáliai régiók keresztény feliratos anyagán. ${ }^{10}$

Az új metodológiájú irányzatok részleges és korlátozott sikerében, az áttörés elmaradásában több tényező szerepet játszhatott, amelyekkel itt részletesen nem foglalkozhatunk. ${ }^{11} \mathrm{Az}$ egyik ilyen tényező azonban nyilvánvalóan az a körülmény volt, hogy akkoriban hiányoztak és ma is hiányoznak a római provinciák feliratkorpuszainak teljességre törekvő és nyelvészetileg megbízható leírásai, amelyekre a nyelvföldrajzi, dialektológiai munkák támaszkodhattak volna. ${ }^{12}$ Üdítő kivételként a közelmúltból csupán Fehér Bence monográfiáját említhetjük Pannonia latinságáról és G. Galdi nyelvtanát a Birodalom keleti provinciáinak névszói morfoszintaxisáról. ${ }^{13}$

A modernitás követelménye azonban nem csak metodikailag fontos, hanem a latin feliratos korpuszok kiadásainak tekintetében is kikerülhetetlen tényező. A 20. század elején ugyanis, amikor Carnoy, Pirson és Skok provincialeírásaikat megalkották, a Mommsen által megalapított „Corpus Inscriptionum Latinarum” még csupán egyharmadát tartalmazta a ma ismert feliratoknak, amelyeknek számát manapság minimum 400000 -

9 Vö. B. Löfstedt: Rückschau und Ausblick auf die vulgärlateinische Forschung. ANRW II, 29, 1. Berlin - New York 1983. 453-479, 477: „zu den wenigen Forschern, die mit strukturalistischen und statistischen Methoden das Vulgärlatein untersuchen und deren Arbeiten immer anregend und oft auch überzeugend sind, gehört József Herman".

${ }^{10} \mathrm{~J}$. Herman: Differenze territoriali nel latino parlato dell'Italia tardo-imperiale: un contributo preliminare. La preistoria dell Italiano. Atti della Tavola Rotonda di Linguistica Storica. Università Ca' Foscari di Venezia 11-13 giugno 1998. Edd. J. Herman - A. Marinetti. Tübingen 2000. 123-135.

${ }^{11}$ Már az új irányzatok képviselői között is jelentős eltérések voltak metodikailag, és nem tett jót a kutatásoknak, hogy elsősorban a vitatható elméleti alapú Gaeng-féle módszertannak (vö. P. A. Gaeng: An Inquiry into Local Variations in Vulgar Latin, as Reflected in the Vocalism of Christian Inscriptions, Chapel Hill 1968) voltak követői, míg az elméletileg szilárd alapokon nyugvó Herman-féle irányzat elszigetelődött ( $J$. N. Adams: i. m.. e két módszertant próbálta kombinálni, sikertelenül). Erről a problémáról lásd: Adamik B.: In Search of the Regional Diversification of Latin: Some Methodological Considerations in Employing the Inscriptional Evidence. Latin vulgaire - latin tardif IX. Actes du IX ${ }^{e}$ colloque international sur le latin vulgaire et tardif, Lyon, 6-9 septembre 2009. Ed. Fr. Biville et al. Lyon (közlésre elfogadva).

12 Így az úttörő metodikájú vizsgálatok nagyrészt kisebb korpuszok vizsgálatára szorítkoztak (pl. Gaeng és követői az ILCV-re), amelyekből viszonylag kis számú adatot lehetett csak kinyerni, és az ezekből levont statisztikai következtetések nem tüntek meggyőzőnek, lásd Adams: i. m. 625 skk.

${ }^{13}$ G. Galdi: Grammatica delle iscrizioni latine dell'Impero (province orientali). Morfosintassi nominale. Roma 2004. Fehér B.: Pannonia latin nyelvtörténete. Budapest 2007. 
re becsülik. ${ }^{14}$ Van olyan terület, mint pl. Hispania, ahol a ma ismert és publikált feliratos anyag a 20. század eleji mennyiségnek majd négyszeresét teszi ki: a latin feliratok száma itt 100 év alatt kb. 6000-ről több mint 22 000-re növekedett. ${ }^{15}$ Ebből következően az említett régi provincialeírások már forrásanyaguk tekintetében is jócskán elavultnak tekinthetők. Ebben a tekintetben még a 60-as 70-es években megjelent néhány provincialeírás is revízióra szorul, ${ }^{16}$ mert időközben fontos új publikációk jelentek meg, új sorozatok indultak, melyek számos új felirattal gyarapították a provinciák feliratos állományát. ${ }^{17}$

Ezek a tényezők, körülmények és nehézségek természetesen Herman József számára is ismeretesek voltak, és éppen ezek motiválták egy új, grandiózus terv megfogalmazására a 80-as évek végén. Az informatika fejlődése nyújtotta lehetőségeket kihasználva - mint az MTA Nyelvtudományi Intézetének igazgatója, ottani kollégái révén - egy komputerprogramot fejlesztetett ki a latin nyelvföldrajzi kutatások előmozdítására. A Late Latin Data Base (rövidítve LLDB, 'Késő Latin Nyelvtörténeti Adattár') című projekt és számítógépes program egy olyan, átfogó jellegű digitális adatbank kiépítését tűzte ki célul, amely rögzítette volna a Római Birodalom összes provinciájának teljes latin feliratos anyagán fellelhető minden, a szöveg szintjén jelentkező, a klasszikus latin nyelvi normától elütő jelenséget, legyen az nyelvi vagy nem nyelvi eredetű eltérés. Ez a digitális adatbank egy olyasfajta információs tárházként mủködött volna, ahonnan merítve ellenőrizni, illetve kiegészíteni lehetett volna a latin nyelvföldrajzi kutatások eddigi eredményeit. Továbbá arra is igen alkalmas lett volna, hogy a nyelvföldrajzi kutatások alapjául szolgáló adatgyűjtemények itt kerüljenek elsődlegesen publikálásra, megszabadítva a dialektológiai publikációkat a gyakran igen terjedelmes adattárak teljes közlésétől. Ez az első számítógépes program Herman József elmondása szerint a kilencvenes évek végén (azzal a számítógéppel egyetemben, amelyre telepítették) működésképtelenné vált, és vele a rögzített adatok elvesztek (pl. egy galliai

${ }^{14}$ Vö. Corpus Inscriptionum Latinarum (tájékoztató füzet; http://cil.bbaw.de/dateien/broschueren. html) Berlin 2001. 16.

${ }^{15}$ G. Alföldy: Il futuro della epigrafia. XI Congresso Internazionale di Epigrafia Greca e Latina. Atti. Roma 1999. 87-102, kül. 89 sk.

${ }_{16}$ Pl. S. Stati: Limba latina în inscripțiile din Dacia și Scythia Minor. București 1961, H. Mihăescu: La langue latine dans le sud-est de l'Europe. București - Paris 1978 és A. Zamboni: Contributo allo studio del latino epigrafico della X Regio Augustea (Venetia et Histria). AIV 124 (1965-66) 463-517., 126 (1967-68) 77-129., Mem. dell'Acc. Patavina, Classe di Sc. Mor., Lett. ed Arti 80 (1967-68) 139-170., Studi linguistici friulani 1 (1969) 110-182.

${ }^{17}$ A. Šašel - J. Šašel: Inscriptiones Latinae quae in Iugoslavia inter annos (1902-1970) repertae et editae sunt 1-3. Ljubljana 1963-1986. (= ILJug), I. I. Russu et al.: Inscriptiones Daciae Romanae 1-. Bucureşti 1975-. (= IDR), I. Stoian et al: Inscriptiones Scythiae Minoris Graecae et Latinae 1-. Bucureşti 1980-. (= IScM), L. Maurin et al: Inscriptions latines d'Aquitaine 1 - Bordeaux 1991 - (= ILA), J. Gascou et al.: Inscriptions latines de la Narbonnaise 1-. Paris 1985-. (= ILN); Pannonia vonatkozásában a RIU kötetein ( $L$. Barkóczi et al: Die römischen Inschriften Ungarns 1-6. Budapest - Bonn 1972-2001.) kívül lásd P. Kovács: Tituli Romani in Hungaria reperti. Budapest 2005 és legújabban P. Kovács - Á. Szabó: Tituli Aquincenses 1-2. Budapest 2009-2010. 
adatgyüjtés). Ránk csak a Késő Latin Adattár angol nyelvü adatgyüjtési utasítása maradt, amely kézirat gyanánt az MTA Nyelvtudományi Intézetében jelent meg 1990-ben vagy 1991 -ben. ${ }^{18}$

\section{Az újraformált LLDB-program létrejötte}

2004 végén Herman József professzor személyes konzultációk során hamar meggyőzött arról, hogy egykori LLDB-programjának újjáélesztése mennyire szükséges és aktuális lenne. A terv megvalósítására kutatócsoportot állítottunk fel, és 2005-ben sikeresen pályáztunk az Országos Tudományos Kutatási Alapprogramoknál (OTKA), aminek következtében 2006-ban elkezdhettük a munkálatokat. A számos munkafázis közül itt most csak kettőt emelek ki.

Először is megfelelő informatikust kellett találni, aki a számítógépes programot újraalkotja. Egy ifjú és tehetséges informatikus, Kiss Márton vállalta a feladatot, akinek egy igen hatékony és jól használható programot sikerült kifejlesztenie, amelyet kezdeményezésére az ELTE honlapjára telepítettünk, a http://ldb.elte.hu/ oldalra. Ezzel a korábbi projekt egyik problémája - ami a program másolataival történő adatgyüjtés során keletkezett részleges adattárak egyesítéséből, egységesítéséből fakad - magától megoldódott. Az internetnek köszönhetően ma mindegyik adatgyűjtő a programnak ugyanazzal a példányával dolgozik.

A másik újítás abban állt, hogy az adatgyűjtés nyelvészeti, filológiai folyamatát öszszekötöttük, egyesítettük az adatrögzítés informatikai munkafázisával. A projekt munkatársait így nem csak arra képeztük ki, hogy adatokat tudjanak gyüjteni a feliratos korpuszokban, hanem arra is, hogy a kinyert adatokat képesek legyenek rögzíteni a digitális adatbázisban.

2006 októberében a program már üzemképes lett, így tesztelés jelleggel elkezdődött a digitális adatlapok rögzítése. 2007 folyamán a program fejlesztése, a folyamatos adatgyüjtéssel, adatrögzítéssel párhuzamosan, egyre intenzívebben folyt, így elkészült a kereső programelem alapváltozata is. 2008-ban az állandó jellegű fejlesztéseken, kisebb finomításokon túl elkészült a program angol felülete is, így a projektet és a szoftvert már nemzetközi közönség előtt is bemutathattuk 2008-ban a Herman József emlékére rendezett szimpóziumon.

${ }^{18}$ J. Herman: Late Latin Data Base: Guidelines for Data Collection. (Institute for Linguistics of the Hungarian Academy of Sciences) Kézirat. Budapest 1990/1991; nem szerepel Herman József bibliográfiájában, vö.: J. Herman: Du latin aux langues romanes 2. Nouvelles études de linguistique historique. (réun. S. Kiss). Tübingen 2006. 243 skk. 


\section{$2.1 \mathrm{Az}$ új LLDB-program müködése}

A „Császárkori latin feliratok számítógépes nyelvtörténeti adatbázisa” c. tájékoztató oldalon (http://lldb.elte.hu/) az adminisztrációs felület menüpont alatt lehet az adatbázishoz hozzáférni, vagy teljes jogú belépéssel (regisztrált adatgyüjtő-adatrögzítő munkatársak részére), vagy korlátozott hozzáférési jogokat biztosító belépéssel (vendégfelhasználók számára). Az adatbázisba belépve a főoldal menüpont alatt lehet a Gyüjtési Utasítást megnyitni, illetve letölteni (az angol felületen értelemszerüen angol nyelven), amely az adatgyüjtés és adatrögzítés részletes szabályait tartalmazza.

Mivel az Adatbázis szívét a felvitt adatlapok képezik, először a digitális Adatlapot mutatjuk be, amelyet némi módosításokkal és kiegészítésekkel a Herman-féle koncepciót követve szerkesztettünk meg. Az „Adatlapok hozzáadása” menüpont alatt lehet az üres adatlapot megtekinteni, amelyet kitöltés után a „felvitel” gombbal rögzíthetünk az Adatbázisban. A kitöltött és felvitt adatlapok az „Adatlapok” menüpont alatt tekinthetők meg. ${ }^{19} \mathrm{Az}$ adatlap szerkezetét kétféle nézetben mutatjuk be, először ún. szerkesztői nézetben, tehát úgy, ahogy az adatgyűjtő-adatrögzítő munkatárs látja és használja munkája során (1. ábra), majd olvasói nézetben, tehát úgy, ahogy a külső felhasználó, látogató számára megjelenik (2. ábra). Illusztráció gyanánt a 750. sorszámú adatlapot választottuk, amelyet a „keresés” menü LLDB-szám rovata segítségével lehet előhívni. ${ }^{20}$ Az ábrákat követi az adatlap rovatainak részletes bemutatása.

\subsubsection{Az adatlap rovatai}

Az első, KÓD-rovat az adat, azaz a szöveg szintjén izolálható, a klasszikus normától elütő nyelvi jelenség kódolására szolgál, legyen szó nyelvi vagy nyelven kívüli (írástechnikai, stb.) eredetű eltérésről. A kódok praktikus okokból többnyire felszíni szerkezeti jelenségeket írnak le (pl. a hangsúlyos ē és $i$ zárt $e$-be való fúzióját értelemszerűen két kód rögzíti: é: > I és í > E; a kettőspont a magánhangzó hosszúságát, az ékezet pedig a hangsúlyosságot jelöli). A kódok kódlistákról (errores non grammaticae, vocalismus, consonantismus és morphosyntactica etc.) kiválasztva illeszthetők be. A kódok száma az igényeknek megfelelően növekszik, jelenleg 256-ra rúg (az eredeti LLDB-Projektben még csak 127 kód szerepelt). Fontos újítás az eredeti projekthez képest, hogy a kódokhoz rendszeresen példák járulnak, amelyek a kódolási folyamatot meggyorsítják, és biztosabbá is teszik (az é: > I kód példája: POSVIRVNT pro posuerunt CIL 5, 1680). Amennyiben az adat kétféleképpen is értelmezhető, a második értelmezési lehetőséget az ALTERNATÍV KÓD mezőben rögzítjük. Az illusztráció gyanánt kiválasztott LLDB750. adatlap kódja: „decl. II pro III”, alternatív kódja pedig: „cett. ad format. adiectivorum pertinentia” (gyűjtőkód).

${ }^{19}$ Itt folynak a rendszeres adatrögzítési munkálatok is, ti. az új adatlapot az előző adatlap módosításával (mutatis mutandis) és új adatlapként való elmentésével generáljuk.

${ }^{20}$ Az új projektben az adatlap sorszáma előtti LLDB mozaikszó a korábbi projekt nevére emlékeztet (Late Latin Data Base). 
Császárkori latin feliratok számítógépes nyelvtörténeti adatbázisa

\begin{tabular}{|c|c|c|c|c|c|c|c|}
\hline főoldal & keresés & adatlapok & adatlap hozzáadása & adataim & kivitel & admin & kilépés \\
\hline
\end{tabular}

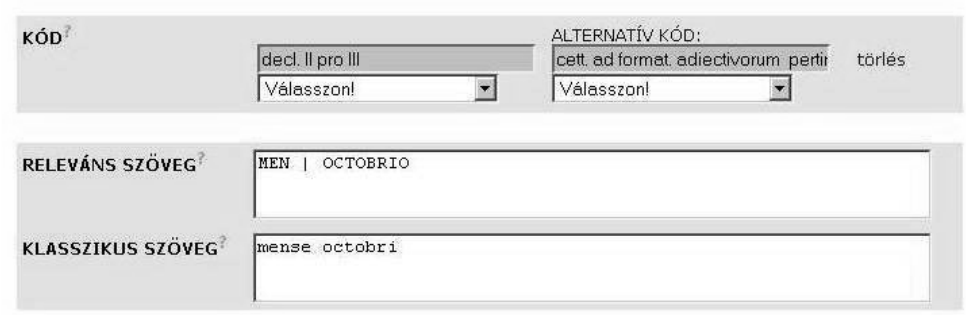

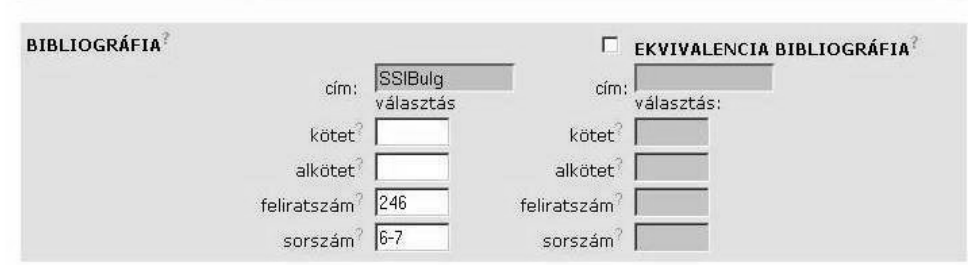

\begin{tabular}{|c|c|c|c|c|}
\hline \multirow[t]{3}{*}{ HELY } & provincia? & Moesia inferior & \multirow[b]{2}{*}{ város választása } & \multirow[b]{2}{*}{ törles } \\
\hline & város, helyiseg & & & \\
\hline & & $\begin{array}{l}\text { Г A város, helység körzetében } \\
\text { szomszédságában }\end{array}$ & (territoriumán), & \\
\hline
\end{tabular}

\begin{tabular}{|c|c|}
\hline KELTEZÉs? & $\begin{array}{l}\Gamma \text { Keltezés egyelốre nem adható meg } \\
\Gamma \text { Adatgyútoo becslése } \\
\curvearrowright \Gamma \text { Kr.e. év: } \square \\
\odot \quad \text { évtōl: } \sqrt{501} \Gamma \text { Kr.e. évig: } \sqrt{600}\end{array}$ \\
\hline
\end{tabular}

\begin{tabular}{|c|c|c|c|c|c|}
\hline FELIRATTIPUS & V keresztény? & $\begin{array}{l}C_{\text {próza }} \\
\text { C vers }\end{array}$ & $\begin{array}{l}\text { ¿ magán? } \\
C_{\text {hivatalos }}\end{array}$ & szöveghordozó Kó & $\nabla$ \\
\hline
\end{tabular}

\begin{tabular}{|c|c|}
\hline $\begin{array}{l}\text { ÉRTÉKELHETŐSÉGI } \\
\text { TÉNYEZOOKK }\end{array}$ & $\begin{array}{l}\Gamma_{\text {elkallódott felirat }} \\
\Gamma_{\text {az adat helyén tớött a felirathordozó }} \\
\Gamma_{\text {az adat helyén a betūk kopottak, nehezen olvasható }} \\
\text { a feliraton szereplók etnikai-nyelvi hovatartozása: }\end{array}$ \\
\hline MEGJEGYZÉS? & $\begin{array}{l}\text { Genauer Fundort ist unbekannt, nach dem Herausgeber starrmt } \\
\text { es aus Nordbulgarien (Hoesia Inferior mit } 2 \text { angegeben in } \\
\text { EDH HDO42944). } \\
\text { Die Form octobrio (ab1. sg.) stellt wahrscheinlich den }\end{array}$ \\
\hline GYÜJTŐ & Adamik Béla \\
\hline
\end{tabular}

1. ábra. Adatlap szerkesztői nézetben 


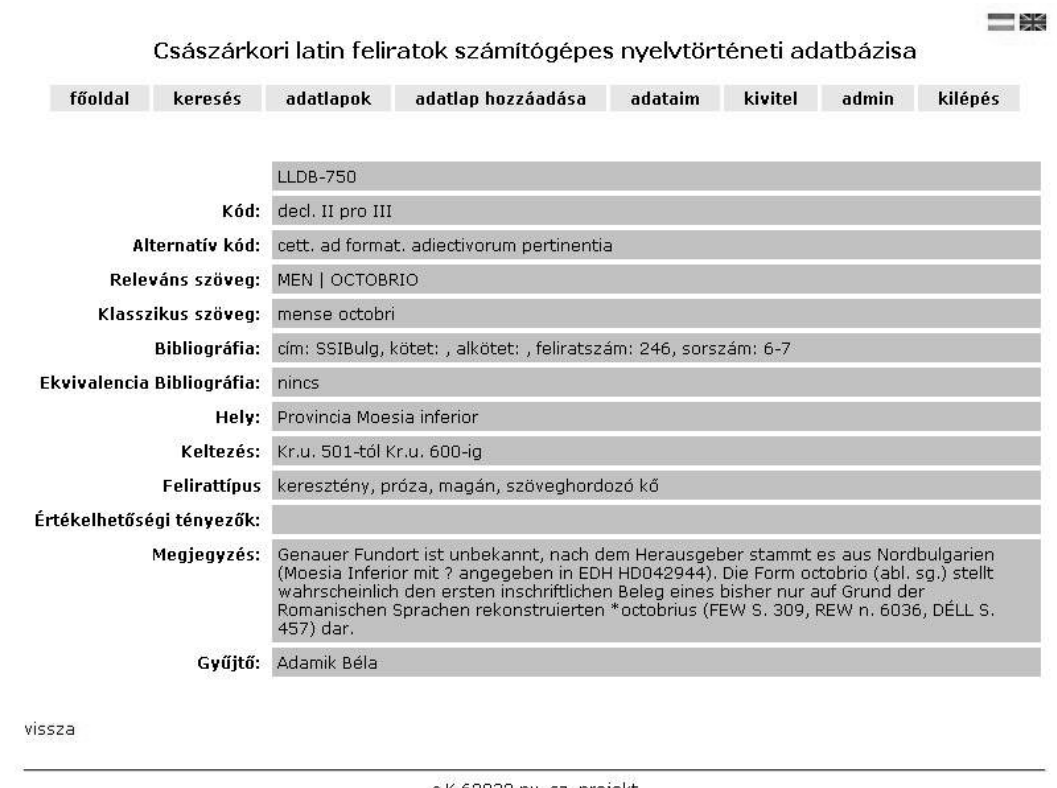

c.K 62032 ny. sz. projekt

2. ábra. Adatlap olvasói nézetben

A második, SZÖVEG-rovat első, RELEVÁNS SZÖVEG mezejébe kerül az adatokat tartalmazó releváns szövegrész, a második, KLASSZIKUS SZÖVEG mezejébe pedig ennek a gyűjtőtől generált klasszikus, normatív latin megfelelője. Az eredeti LLDBprojektben még csak a releváns szöveg került rögzítésre, a normatív megfelelő nem. A KLASSZIKUS SZÖVEG alrovattal egyfajta szótár jön létre, amely jól használható többek között keresésre (pl. ha valaki a VIXIT variánsaira kíváncsi, a Kereső programelemben eme alrovat segítségével hamar visszakeresheti azokat). ${ }^{21}$ Az LLDB-750. adatlap RELEVÁNS SZÖVEG mezejébe MEN | OCTOBRIO, a KLASSZIKUS SZÖVEG mezejébe pedig mense octobri került. E fontos nyelvi lelethez még visszatérünk a MEGJEGYZÉS rovat ismertetésekor.

A harmadik, BIBLIOGRÁFIA rovatban történik az adat bibliográfiai meghatározása, a CÍM, KÖTET, ALKÖTET, FELIRATSZÁM és SOR SZÁMA alrovatok értelemszerű kitöltése révén. A CÍM rovatba az adott gyűjtemény rövidített címe kerül beillesztésre, majd a többi alrovatot töltjük ki szükség szerint, és a felirat adatot tartalmazó sorát is minden esetben megadjuk (a korábbi projektben csak a 10 sornál hossz-

${ }^{21}$ Az alrovat létrehozását annak idején Kiss Gábor javasolta, aki Herman József világhírü vulgáris latin tankönyvének magyar kiadásában elévülhetetlen érdemeket szerzett. 
abb feliratok esetében volt kötelező ennek megadása). Így az LLDB-750. adatlap BIBLIOGRÁFIA rovata az SSIBulg22 rövidített címet, a 246-os feliratszámot és a 6-7-es sorszámot tartalmazza. A sorszámok konzekvens megadása révén az adatok bibliográfiai meghatározása a korábbiaknál pontosabbá vált (pl. egyazon feliraton ugyanannak az adatnak eltérő sorokban való előfordulása rögzítésekor).

A negyedik, HELY rovatban történik a felirat lokalizálása. Ennek során a felirathordozó tárgy lelőhelyét vagy felállítási, származási helyét a PROVINCIA és a VÁROS / HELYSÉG mezők (listákról való választás útján történő) kitöltésével határozzuk meg. Az LLDB-750. adatlapon csak a provinciát lehetett megadni, mert nem ismert a felirat pontos lelőhelye (a kiadó szerint Észak-Bulgária, feltehetőleg Moesia Inferior; a bizonytalanságot az EDH kérdőjellel jelzi ${ }^{23}$ ). Az általánosabb eset azonban az, hogy a feliratok antik városok, helységek szerint is lokalizálhatók.

Az ötödik, KELTEZÉS-rovatban történik az adatot tartalmazó felirat keletkezési idejének meghatározása, ami nem mindig egyszerủ. Sok, főként régebbi kiadásban, így sajnálatosan a feliratok legalapvetőbb korpuszában, a CIL-ben, de olykor még modern kiadványokban (pl. ILN) sem (vagy csak ritkán) találhatók datálások. Ennek oka leginkább abban a körülményben keresendő, hogy egészen a legutóbbi időkig a keltezés megadása nem tartozott az epigráfiai leírás kötelező alapkritériumai közé. Szerencsére az újabb kiadványok egyre inkább és egyre gyakrabban közölnek keltezéseket, így, ahol csak lehet, nem a CIL régi köteteiből, hanem modernebb kiadványokból gyüitünk adatokat. Az LLDB-750. adatlap esetében, Beševliev datálása alapján, a 6. századot lehetett megadni (numerikusan megadva: 501-600).

Az ötödik, FELIRATTÍPUS nevü rovat célja, hogy a nyelvi analízis, illetve a nyelvi, szociolingvisztikai adatértékelés megkönnyítése céljából a felirat bizonyos jellegzetességeit rögzítse. Regisztráljuk, hogy keresztény vagy nem keresztény, hogy verses vagy prózai és hogy magán- vagy hivatalos jellegü-e a felirat. Itt adjuk meg a felirathordozó anyagát is. Az LLDB-750. adatlap e rovata szövegünket keresztény, prózában írt, kőbe vésett magánfeliratként határozza meg.

A hetedik, ÉRTÉKELHETÖSÉGI TÉNYEZÖK nevű rovat segíti az adatok kiértékelését. Itt rögzítjük, ha a felirat elkallódott, ha az adat helyén törés, illetve jelentős sérülés van a felirathordozón, vagy ha az adat helyén a betűk kopottak, nehezen olvashatók. Ezek a körülmények ugyanis jelentősen befolyásolják egy adat felhasználhatóságát, akárcsak az a körülmény, ha a feliraton valószínűsíthetően nem latin anyanyelvủ személy(ek) szerepel(nek), Ez utóbbi körülményt „A feliraton szereplők etnikai-nyelvi hovatartozása" mezőben lehet jelezni (de csak akkor, ha a gyüjtemény vagy maga a felirat erre a körülményre utalást tesz). Az LLDB-750. adatlap esetében e rovat kitöltetlen maradhatott, ami az adat felhasználhatósága szempontjából a legkedvezőbb eset.

22 SSIBulg = V. Beševliev: Spätgriechische und spätlateinische Inschriften aus Bulgarien. Berlin 1964.

${ }^{23} \mathrm{EDH}=$ Epigraphische Datenbank Heidelberg (http://www.epigraphische-datenbank-heidelberg. de/), a felirat ott a 042944 HD-számon került felvételre. 
Végül a nyolcadik, MEGJEGYZÉS-rovat biztosít helyet a nyelvi értelmezést elősegítő, árnyaló esetleges megjegyzéseknek, amelyeket - az Európai Unió nyelvpolitikájával összhangban - a Nemzetközi Vulgáris és Kései Latin Konferencia munkanyelvein lehet megtenni: latin, angol, francia, német, olasz és spanyol nyelven. Az LLDB-750. adatlap e rovatában a következő megjegyzés olvasható: ${ }^{24}$ „Az octobrio (abl. sg.) alak az első feliratos példája az eddig csak a román nyelvek alapján rekonstruált "octobrius formának (FEW S. 309, REW n. 6036, DELL S. 457)." 25

Az összes rubrika kitöltését követően az adatlapot rögzíthetjük az adatbázisban. Később az adatlap módosítható vagy akár törölhető is. Ugyanarról a feliratról további adatok egyszerűen a „Mentés új adatlapként (új sorszámmal)” funkció alkalmazásával rögzíthetők.

\subsubsection{A kereső programelem}

Egy adatbank akkor kezd élni, akkor lesz igazán használható, ha részletes kereső funkcióval látjuk el. Az új LLDB-adatbázisban már működik a kereső programelem, amelyben sorszám alapján magára az adatlapra, továbbá az adatlapok egyes rovataira, illetve a rovatok bármilyen kombinációjára lehet keresni, sőt az eredmények exportálhatók is.

Például, ha valaki a Syncope kóddal felvitt adatlapokra kíváncsi, akkor a (2009 eleji állapot szerint) 81 találatot kap, amiből (területi szűkítéssel) 31-et talál Aquitaniában (és további területi szűkítéssel) 7-et Mediolanum Santonumban. A 31 aquitaniai példa közül (időbeli szűkítéssel) 10 eset a principátus korára datálható (3 az 1. századra, 1 az 1-2. századra, 2 a 2. századra és 4 a 2-3. századra), 14 keresztény feliratos eset a dominátusra (4 a 6. századra, 4 a 7. századra és 6 a 4-6. századra), 7 eset pedig datálatlan maradt. Ha a Syncope 81 példáját csak kronológiailag vizsgáljuk, akkor azt találjuk, hogy a 15 datálatlan eset levonásával 45 darab esik az 1-3. századra és 21 darab a 4-7. századra (ennél természetesen szűkebb időszakok is vizsgálhatók, akár csak egyetlen év is.

Mint említettük, az adatlapok rovatai bármiféle kombinációban kereshetők, és tervezzük a keresőelem további funkcionális bővítését is. Bár az adatlapok száma lendületesen gyarapszik (2010 január végi állapot: 6051), az adatbázis jelenlegi állapotában még nem elég gazdag ahhoz, hogy dialektológiai következtetéseket vonjunk le belőle, a folyamatos építkezés, az adatlapokkal való egyre intenzívebb feltöltés révén azonban már belátható időn belül a latin dialektológiai kutatások alapvető eszközévévé válhat.

3. A Program fejlesztése: tervek és lehetőségek

Feltehetőleg az eddigiekből már világossá vált, hogy mekkora jelentőséggel bír a latin dialektológiai kutatások számára egy, a Római Birodalom latin feliratainak vulgáris latin jelenségeit feldolgozó digitális adatbázis. A szakirodalomban újra meg újra fel-

${ }^{24}$ Az SSIBulg 246-os feliratainak vulgarizmusairól 12 adatlapot rögzítettünk: LLDB 750 (Adamik B.), LLDB 721-730, illetve 3422 (Zalán L. Sára).

${ }^{25} \mathrm{FEW}=W$. von Wartburg: Französisches Etymologisches Wörterbuch. Basel 1946-, REW $=W$. Meyer-Lübke: Romanisches Etymologisches Wörterbuch. Heidelberg 1935, DELL = A Ernout - A. Meillet: Dictionnaire étymologique de la langue latine: Histoire des mots. Paris $1967^{4}$. 
merülő szkepszis ellenére ugyanis továbbra is a latin feliratok százezres nagyságrendü korpusza biztosítja a latin dialektológia kutatói számára azt az elsőrendủ forrásanyagot, amelyre építve a latin nyelv tekintetében releváns dialektológiai, nyelvföldrajzi kutatások építhetők. ${ }^{26} \mathrm{~A}$ feliratos korpuszok fokozatos és folyamatos feldolgozása révén egyre biztosabb bázis építhető ki effajta vizsgálatok számára. Célterületi szempontból is szeretnénk az adatbázist bővíteni: a projektben kijelölt területekhez, tehát az illyricumi avagy dunai provinciákhoz, valamint Britanniához és Galliához 2010-től tervezzük hozzávenni a germaniai, az észak-italiai és a hispaniai provinciákat. Különösen Hispania tünik kecsegtetőnek, ahol, mint említettük, a feliratok száma egy évszázad alatt 6000-ről több mint 22000-re emelkedett.

A feliratos korpuszok feldolgozásával és az adatlapok rögzítésével párhuzamosan szándékunkban áll, hogy az épülő adatbázis felhasználhatóságát fokozzuk, egyrészt a kereső programelem további fejlesztése, másrészt pedig a megjelenítés, a vizualizálás megteremtése révén. Ez utóbbi keretében tervezzük az adatlapok halmazaiban feltárható adatstruktúrák (a különféle hibatípusok megoszlása, gyakorisága) grafikonos ábrázolásának megoldását és a területi megoszlások ábrázolásához nélkülözhetetlen nyelvatlaszos megjelenítés kialakítását is. E fejlesztések révén az Adatbázis remélhetöleg egy olyan, mind területileg, mind kronológiailag jól strukturált és statisztikailag reprezentatív adathalmazt tud biztosítani a latin dialektológiai kutatások számára, amely eloszlathatja a még mindig fel- felmerülő kételyeket a latin feliratos anyag dialektológiai felhasználhatóságát illetően. ${ }^{27}$

E fejlesztések és tervek akkor tudnak megvalósulni, ha a 2009 végéig az OTKA támogatását élvező projekt 2010-től további támogatásra talál. ${ }^{28} \mathrm{~A}$ projekt további fejlesztéséhez biztos alapokat nyújtanak az eddig elért eredmények. Létrejött az adatbázis-kezelő program, kiépültek alapvető programelemei, felállt egy jól kiképzett csapat, amellyel elkezdtük az adatbázis feltöltését adatlapokkal. A folyamatos csapatmunkának köszönhetően a célprovinciák korpuszainak feldolgozásai egyre teljesebbé válnak. Megkezdtük a projekt nemzetközi szintű megismertetését is, először 2008-ban a Herman József emlékére megrendezett szimpóziumon, majd 2009-ben a lyoni nemzetközi vulgáris latin konferencián. ${ }^{29}$ Remélhetőleg e minden tekintetben hazai hátterü, de európai horizontú projekt idővel külföldi munkatársakra és támogatókra is talál, így szélesebb körű, nemzetközi együttműködésben kiteljesedve váltja valóra egykori iniciátora, Herman József álmait.

${ }^{26}$ Ehhez a hatalmas feliratos korpuszhoz járulhatnak kiegészítő jelleggel más primer források is, pl. papiruszok és más nem kéziratos hagyományozású szövegcsoportok is (vö. Adams: i. m. 651: „non-epigraphic documentary corpora”), de ezek jellegüknél és hagyományozódási sajátosságaik miatt csak mellékszerepet játszhatnak a kutatásban.

${ }^{27}$ A (nagyrészt alaptalan) szkepszist Adams: i. m., a (megalapozott) optimizmust pedig Herman József képviseli, vö. Herman: i. m. (10. jegyz.), mindehhez vö. Adamik: i. m. (11. jegyz.).

${ }^{28}$ E beszámoló 2010 januári elkészítése közben derült ki, hogy az OTKA a 2010-2013-as 2. szakaszra (K 81864) is támogatja a projekt munkálatait, amiért itt is köszönetet mondunk az OTKÁ-nak.

${ }^{29}$ Vö. Adamik: i. m. ("jegyz.) és Adamik: i. m. (11. jegyz.). 